\title{
Obraz przestrzeni dowolnej według Gilles’a Deleuze’a
}

\begin{abstract}
Lipiński Kamil, Obraz przestrzeni dowolnej według Gilles’a Deleuze’a [The image of "any-space whatever" according to Gilles Deleuze]. „Przestrzenie Teorii” 31. Poznań 2019, Adam Mickiewicz University Press, pp. 261-270. ISSN 1644-6763. DOI 10.14746/pt.2019.31.14.
\end{abstract}

The subject matter of the article is Gilles Deleuze's considerations on the concept of "any-space whatever" and its application in the cinema and the theater. This space is an outcome of the sensorimotor crisis as the development of Henri Bergson's conception of duration to determine the potential transformations of modern cinema in the post-war period. It is expressed by a potential singularity that finds its locus in pure optical and sound situations. This conception reveals the correlation between the real and virtual connections defined by a genetic sign which relies upon differentiation. As a space characterized by an affection - image is experienced from its inside to define both disjoint and empty spaces. Such affect often emerges in a range of colors to outline the places marked by emptiness. It is strictly associated with "geometrical" orientation actualizing itself via the qualisign. Thus, this article defines the space in terms of the circuit of virtuality and actuality in time-image which crystallizes both in the cinema and TV dramas of potential exhaustion of three languages in theater performances. Namely, the first one is disruptive and enumerative; the second language consists of voices and combinative flows and the third one reunites the previous ones as the language of images, sounds, and coloring which is a movement between words.

KEYWORDS: any-space whatever, potentiality, audiovisuality

W niniejszym szkicu zostanie podjęta próba doprecyzowania pojmowania przestrzeni dowolnej zaproponowanej przez Gilles'a Deleuze'a w jego dwutomowym dziele Cinéma 1. L'Image-Mouvement i Cinéma 2. L'Image-Temps (1986). Realizacji tego zadania poświęcona jest pierwsza część artykułu, skupiona na dookreśleniu koncepcji przestrzeni dowolnej po to, by wydobyć fragmentaryczna, podzieloną wykładnię obrazu w jego filozofii. W drugiej zaś części nawiązuję do szkicu L'Epuisé, suite à Samuel Beckett (1992), w którym dookreślam konfigurację możliwości wyczerpania. Projektowana perspektywa ma na celu uchwycenie rozplanowania koncepcji przestrzenności na gruncie filozofii Deleuze'a w nawiązaniu do historii kina i sztuki teatralno-telewizyjnej.

Punktem wyjścia rozważań będzie postrzeganie potencjalności przestrzeni tkwiącej w obrazie Gilles'a Deleuze'a, stanowiące narzędzie poznawcze wyznaczone przez postbergsonowską epistemologię i będące „swoistym rozwinięciem Bergsonowskiego znaku" ". Zarysowane w tym ujęciu Bergsonow-

${ }^{1}$ W. Chyła, Gilles Deleuze o filmowym „obrazie-ruchu” $i$,obrazie-czasie”. Wprowadzenie do lektury ksiażek G. Deleuze“a poświęconych kinu, „Kwartalnik Filmowy” 1993, nr 1, s. 14. 
skie trwanie funduje percepcję czasu w kategoriach przestrzeni dowolnej. Poprzez odejście od schematu-motorycznego Deleuze kreuje myśl estetyczną poświęconą przestrzeni dowolnej (espace quelconque), uważanej za rezultat przejścia z kina obrazu-ruchu do obrazu-czasu w wyniku kryzysu sensomotorycznego ${ }^{2}$. Obraz-czas wyraża się poprzez wibrację w afekcie rezultatu zerwania z łącznikiem sensomotorycznym opartym na powiązaniu percepcji $\mathrm{z}$ akcją w obrazie-ruchu. Kryzys ten wiąże się z wewnętrznym zerwaniem (brisé de dedans) sensomotorycznej natury obrazu-ruchu opartej na rozdwojeniu. Efektem tych działań jest odejście od motoryczności poprzez orientację $\mathrm{w}$ stronę percepcji powiązanej z akcją i nawiązanie kontaktu z myśla, obrazem. W rezultacie „warunki sensomotoryczne zanikaja, transformuja przestrzenność i możliwe sposoby subiektywizacji tych przestrzeni”'3. Pozwala to na dookreślenie potencjalności tkwiącej w obrazie i nakreślenie nowych stosunków przestrzeni w kinie powojennym poprzez zerwanie z sensomotorycznościa. W tej sytuacji wyłania się „przestrzeń doskonale niepowtarzalna. Traci swoja jednorodność, to znaczy zasadę swoich zależności metrycznych lub łączliwości swoich części, że połączenia można dokonywać na nieskończenie wiele sposobów" . Sygnalizowana potencjalność zachodząca między tymi obrazami przedstawia obraz-afekt nawiązujący do jakości specyficznych twarzowości ${ }^{5}$, aktualizowanych $\mathrm{w}$ obrazie akcji osadzonym w przestrzeni określonej. Owa przestrzeń jest rezultatem przeobrażeń kina powojennego, modernistycznego, kina nowofalowego. Pozwala ona zarysować, skonceptualizować i doprecyzować wizję świata pełną niejednoznacznych miejsc. Można pośród nich wydobyć potencjalna „osobliwość, odnajdująca swoje locus w czystych sytuacjach optycznych i dźwiękowych" utożsamiana z krystalizacją „przestrzeni dowolnej (espace quelconque) w obrazie”. Zauważmy, iż przestrzeń dowolna jest wyrazem deterytorializacji, będącej innym znakiem na określenie bipolarnego ruchu obrazu w kinie modernistycznym, począwszy od lat sześćdziesiątych. W odróżnieniu od kliszy obrazu-ruchu zrywa on w kinie modernistycznym z konwencjonalnymi sposobami widzenia i zaciera istniejące już formy motoryczności celem odsłonięcia nowych możliwości egzystencji. Potencjalność przestrzeni dowolnej krystalizuje się pod wpływem

Owo założenie opiera się na klasycznym podziale w filozofii Deleuze’a na potencjalność i rzeczywistość.

${ }^{2}$ R. Bensmaïa, L'«espace quelconque» comme "personage conceptuel», "Iris" 1997, no. 23, s. 33.

${ }^{3}$ A. Sauvagnargues, Deleuze et l'art, Paris 2015, s. 244.

${ }^{4}$ G. Deleuze, Kino. Obraz-czas. Obraz-ruch, przeł. J. Margański, Gdańsk 2009, s. 122.

${ }^{5}$ Tamże.

${ }^{6}$ Wydaje się, że bardziej adekwatne byłoby tłumaczenie: „przestrzeń jakakolwiek”, co również znajduje swoje przełożenie w tłumaczeniu na język angielski - „any-space-whatever”. Tym niemniej pozostaję przy wersji zaproponowanej przez Janusza Margańskiego. 
deterytorializacji w obrazie i jednocześnie odzwierciedla obraz prawdziwych połączeń lub wirtualnych rozłączeń (conjunctions). Jedną ze znamiennych cech przestrzeni dowolnej jest rozłączność charakteryzująca kompozycję bipolarną oraz konstytuująca znak genetyczny i zróżnicowany. Obrazy przestrzeni dowolnej wzbudzają zarówno emocjonalną, jak i instynktowną odpowiedź na definicję obrazu-afektu ${ }^{7}$. Afekt ma intensywną jakość określoną wzdłuż linii i cech twarzowości. Wtenczas siła intensyfikuje potencjalizację w przestrzeni. Obraz ten jest określeniem „afektu wyrażonego (lub przedstawionego) w przestrzeni dowolnej. Przestrzeń dowolna jest albo przestrzenia pusta, albo przestrzenia, w której ciagłość części nie jest stała czy ustalona”8. W przestrzeni dowolnej percepcja problematyzuje się w rozgrywanej akcji odczuwanej z wewnątrz. Odmiana cieni, bieli i kolorów określa w ten sposób

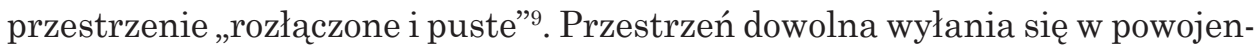
nej sytuacji, opisując opuszczone przestrzenie, biedne przestrzenie miejskie i ujawnia motywację do realizacji w stanie ruchu czystych sytuacji optycznych i dźwiękowych ${ }^{10}$. W trwaniu aktualizują się przestrzenie, zwłaszcza te miejskie, zróżnicowane tkanki uchwycone we fragmentarycznych sytuacjach obrazach-afektów różnych od obrazów-akcji. Za najbardziej wyrazista ilustrację przestrzeni dowolnej można uznać „puste przestrzenie w dziełach filmowych Michelangela Antonioniego, grand ensembles w filmach Jean-Luca Godarda, banlieue Marguerite Duras, amerykańskie inner-city"11. Tytułem przykładu zauważmy, iż wymienione przestrzenie potencjalne aktualizują się za pomocą współznaku (quasi-znak, qualisigne lub postsigne), umożliwiając dookreślenia „czystych sytuacji optycznych i dźwiękowych”. Podział ten zaś służy do wyrażenia dwóch natur: rozłączenia i pustki, tego, co „przed” i tego, co „po” ${ }^{12}$. Warto zauważyć, iż pierwsza z wymienionych cech - rozłączność stanowi główną cechę kina powojennego wyłaniającego „zniszczone budynki w trakcie konstrukcji: ich potencjał w możliwościach i jakościach zaznaczających zaktualizowane miejsca" ${ }^{13}$. Owe czyste sytuacje optyczne i dźwiękowe oznaczają puste tereny i zróżnicowane miejsca, będące wyrazem ilustracji obrazu - afektu podporządkowanej obiegowi aktualności i wirtualności. Jedna z dobitnych ilustracji przestrzeni dowolnej, zdaniem Deleuze'a, jest film Zaćmienie (1962) w reżyserii Michelangela Antonioniego, znaczony przez pustkę i opuszczenie. Można w nim wyróżnić zagubione spojrzenie powsta-

${ }^{7}$ L.U. Marks, The Skin of the Film. Intercultural Cinema, Embodiment, and the Senses, Durham \& London 2000, s. 28.

${ }^{8}$ G. Deleuze, Kino: Obraz-ruch..., s. 565.

${ }^{9}$ Tamże, s. 132.

${ }^{10}$ Tamże, s. 133.

${ }^{11}$ R. Bensmaïa, dz. cyt., s. 31.

${ }^{12}$ G. Deleuze, Kino: Obraz-ruch..., s. 132.

${ }^{13}$ Tamże, s. 168. 
jące nie tyle „z braku kogoś innego, ile z braku siebie samych” w Zawodzie: reporter $(1975)^{14}$. Należy w tym miejscu zwrócić uwagę na dwa bieguny: obiektywny i subiektywny, realny i nierealny, fizyczny i psychiczny. Znamienna cechą przestrzeni we francuskiej Nowej Fali jest horyzontalizm, obejmujący sceny spacerowania, błąkania się, poczynając od rozluźnienia więzów sensoryczno-motorycznych, do spiętrzenia się sytuacji optycznych i dźwiękowych ${ }^{15}$. Zasadniczą cechą tej przestrzeni dowolnej nie są współrzędne, lecz „czysty potencjał, odsłaniający jedynie czyste Potencje i Jakości, niezależnie od stanów rzeczy lub środowisk, które je aktualizuja”" ${ }^{16}$. Tym, co różni „geometrycznie” postrzeganą przestrzeń dowolną od „przestrzeni określonej”17, jest padanie cienia wydobywające głębię i otwarcie duchowe. Pozwala ona przezwyciężyć wszystkie aspekty ,formalne i ograniczenia materialne w przestrzeni fizycznej, gdzie stanowi ilustrację tego, co porowate i zamknięte, a jednocześnie umożliwia uchwycenie czystych miejsc możliwości"18.

Jedną z najbardziej specyficznych cech potencji wydobywającej się z koloru jest element wypełniający przestrzeń aż do pustki. Ową przestrzeń dowolną wyraża genetyczna forma obrazu-afektu ${ }^{19}$. Przestrzenie genetycznie związane z afektem kierują się w stronę próżni w przestrzeni dowolnej, z której wydobywa ona potencjalność kolorystyczną sceny. Wyrazista perspektywa zakłada i odzwierciedla „zdolność transfiguracji i antycypacji rzeczywistości przeciw kliszom"20 odnajdywaną w przestrzeni pozbawionej afektu, gdzie „przestajemy odczuwać lub działać, wkraczając w ucieczkę, włóczęgę, podróż w tę i z powrotem, mgliście obojętni na to, co się zdarzy, niezdecydowani, co trzeba zrobić" ${ }^{21}$. Potencjalna dowolność powstaje zaś poprzez demontaż przestrzeni klasycznej, abstrahując od przynależności do miejsca, konkretnych współrzędnych czasoprzestrzennych, wymykając się wobec przestrzeni pustej. Nie kategoryzuje ta przestrzeń dowolna abstrakcyjnego świata, miejsca jako pojedynczej formy, lecz stanowi miejsce połączenia wirtualnego, miejsce możliwości. Przebiega ten obraz modernistyczny w dwóch kierunkach, mając na celu, z jednej strony, nacechowanie niestabilności, heterogeniczności, nieobecności miejsca. Z drugiej zaś strony obfituje w bogactwo potencjalności i pojedynczości, a co za tym idzie, otwiera możliwość aktualizacji.

Problematyka potencjalności przestrzeni dowolnej staje się przedmiotem rozważań Deleuze'a nie tylko w kontekście poświęconym obrazom

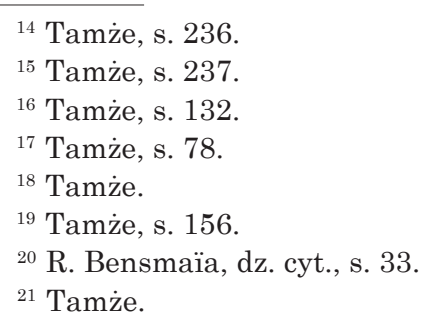


w kinie, lecz również w nawiązaniu do rekonstrukcji zapisów telewizyjnych dramatów Samuela Becketta wystawionych w teatrze. Przyjrzyjmy się owej wykładni, nawiąując do „ostatniego wielkiego tekstu Deleuze'a”22. Problematyka nakreślona $\mathrm{w}$ tym szkicu dotyczy rewaloryzacji rozproszenia energii w przestrzeni dowolnej wizualizowanej w obrazie. Owej wizji towarzyszy rewaloryzacja rozproszenia energii w przestrzeni dowolnej wizualizowanej w obrazie. Tom Conley, rekonstruując ujęcia Deleuze'a, pisał: „zdarzenie teatralne zaznacza się przez rozproszenie całej przestrzeni wyobrażonej, przestrzeni, która posiadała obecność uprzednio ustanowiona" ${ }^{23}$. Deleuze zauważał niejednokrotnie w swoich rozważaniach, iż „wyczerpanie jest czymś znacznie większym niż zmęczenie" ${ }^{4}$. W ujęciu Deleuze'a kształtuje się ona przez nieobecność tego, co możliwe poprzez jego wyczerpanie. Rozpoczyna się ten szkic poprzez wyłożenie podwójnego charakteru wyczerpania i zmęczenia. Wyczerpanie tego, co możliwe w wyniku podziału, rozumiemy jako alternatywę i potencjalność. Nie idzie o zdefiniowanie znaczeń poprzez ich wyczerpanie, ile o dookreślenie objawów wiązanych $\mathrm{z}$ wyczerpaniem fizjologicznym, podporządkowaniem kombinacji i zniesieniem rzeczywistości. Innymi słowy, jest ono kresem wszelkiej możliwości. W rezultacie autor L'Epuisé mnoży podwojenia, opierając się na koegzystencji wyczerpania i kreacji tego, co możliwe. Oznacza to, iż możliwość nie zaistnieje, dopóki nie zostanie wykreowana, aktualizując się w ramach projektu przygotowywanego do realizacji. Obszarem, w którym się ona realizuje, jest przestrzeń dowolna wyczerpująca się w wyczerpaniu tego, co możliwe, i możliwość samego wyczerpania. Ta podwójna perspektywa pozwala na realizację tego, co możliwe, w zależności od poszczególnych „celów, projektów, preferencji” ${ }^{25}$. Zasadniczą cechą tych wykluczeń są wariacje, substytucje, wszystkie ekskluzywne rozłączności. Różnorodność sytuacji powstałych wiąże się z wykluczeniem opartym na formule kopisty Bartleby'ego z noweli Hermana Melville'a: I would prefer not to. Znamienna cechą języka przechodzącego poprzez całe dzieło Becketta jest seria wyczerpań, rozpatrywana w nawiązaniu do trzech języków badajacych spektrum myślenia o wyczerpaniu ${ }^{26}$. Proponowany przez Deleuze'a język wyraża specyfikę dramatu Watt, znaczoną przez ,język nazw odwołujących się do światów przedmiotów”"27. W tym ujęciu przedstawia

${ }^{22}$ F. Zourabichvili, Deleuze et le possible (de l'invontolarisme en politique), [w:] Gilles Deleuze. Une vie philosophique, Paris 1998, s. 336.

${ }^{23}$ T. Conley, L'événement-cinéma, „Iris” 1997, nr. 23, s. 77.

${ }^{24}$ G. Deleuze, L'Epuisé, suite à Samuel Beckett, postface à "Quad”, de Samuel Beckett, Paris 1992, s. 57.

${ }^{25}$ Tamże.

${ }^{26}$ R. Bellour, La chambre, [w:] tegoż, L'entre images 2, Paris 1999, s. 303.

${ }^{27}$ Tamże. 
on język rekwizytów rozsianych przez niego w różnych formach obejmuje skarpetki, trzewiki, buty, pantofle, komodę, toaletkę, łóżko, okno, ogień. $\mathrm{W}$ tej dynamice powiązanie obiektów wpisanych w rezerwuar przestrzeni dowolnej wyklucza pozostałe możliwości ich połączeń. Jedno wykluczenie obiektów prowadzi zaś do włączenia innych możliwości. W tej perspektywie postrzegany język atomiczny i wyliczający: „zastępuje własności lub kombinacje relacji syntaktycznych. [...] utracił swoje bariery i atom uwalnia się pustce oświetlonej, niepersonalnej i jednak pojedynczej [...] nie ma już Siebie, żeby odróżnić się, ani pomieszać z innymi”28.

W wyniku wyczerpania tego, co możliwe, wyłania się nowy sens oparty na powiązaniu z innymi. Wyczerpanie sensu poprzez wyczerpanie $\mathrm{w}$ seriach popada w aporię odnajdywanej w powieści Watt. Wyróżniony wśród nich język głosu dookreśla w dziele Becketta „światy możliwe, wyczerpane w historiach" ${ }^{29}$. Pozwala on na wynalezienie przestrzeni złożonej ze wspomnień i na zwielokrotnienie dróg. Owa sytuacja odzwierciedla, jak język ten przechodzi przez opowieści (The Unnamable) napotykane zarówno w teatrze, jak i w radiu. Krystalizuje się na podstawie kombinacji kształtującej się w „przepływie zdolnym do pomieszania”30. Tym różni się on od pierwszego języka, że nie słychać już słów w pierwszej osobie, lecz głos innego właściciela przedmiotów. To, co „inne”, przedstawia możliwe światy, w obrębie których głos zdaje się stanowić różnorodna relację z rzeczywistości, budując historię. Według Deleuze'a uniknięcie aporii staje się możliwe jako efekt tego, co niewyczerpywalne w seriach wszystkich wyczerpań osadzonych pomiędzy „dwoma kategoriami lub wariacjami głosu kreowanymi w przepływie już oczekującej serii ulegającej wyczerpaniu zanim wyłoni się większa ilość możliwości”" Mając na uwadze dookreślenie specyfiki trzeciej postaci języka, Deleuze nakreśla obraz związków wizji i muzyki, będących wyrazem pierwszego z nich, następnie drugiego, by wreszcie ukształtować ostatni. Jedna z bardziej znamiennych cech jest to, iż „dotyka ograniczeń immanentnych, poniżej słów i ich historii, które zmierzają na zewnątrz do tego, co widziane lub słyszane, do tego, co Beckett nazywał obrazem"32. Obraz jest postrzegany w dwójnasób: jako wizualny, jak i dźwiękowy. Tak rozumiana dwoistość wydobywa zeń „język przestrzeni dowolnej, gdzie obraz jest niezdefiniowany, rozprasza się, jak tylko się pojawia, wyczerpuje się sam, wyczerpując cały język”33. Wspo-

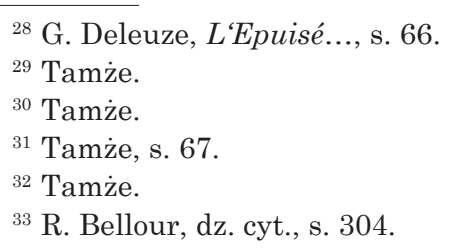


mniany język stanowi coś, co wykracza poza to, co osobiste, racjonalne, i jednocześnie wkracza na poziom boski. Wyczerpanie potencjalności powstaje w tym stanie przestrzeni dowolnej i kiełkuje w ,języku obrazów i przestrzeni”, co prowadzi do „wyczerpania przestrzeni”" Zapis filmowy teatru „odnajduje w telewizji tajemnicę swojego asamblażu w głosie, preegzystuje w obrazie, ilekroć przybiera kształt. Jest specyficzną cechą dzieła telewizyjnego" ${ }^{35}$. Jednocześnie w tym zapisie filmowym sztuki teatralnej Trio de fantôme głos przechodzi między cisza, piosenką i muzyką. Obraz uosabia w takim sensie sztukę, malarstwo, muzykę i nie znajduje żadnego innego celu obrazu aniżeli nomadyczna wędrówka, bowiem jego treść jawi się całkiem zubożała, przeciętna, pozbawiona potencjalności. Poprzez wędrowanie w przestrzeni audiowizualności język ten przechodzi „przez teatr, znajduje swoją tajemnicę w telewizji, gdzie przybiera kształt w potencjalności tak długo, jak wykonanie wydarzenia jest możliwe" ${ }^{36}$. Mamy w tym miejscu do czynienia z wibracja, jaką cechuje audiowizualność, aby uchwycić „,refren wizualny lub dźwiękowy, tak jak refren pojawia się jako refren obrazów złożonych, dekomponowanych, jak również przestrzeń powracająca jako refren napędowy w pozycjach, krokach"37. Potencjalność tego języka w przestrzeni pozbawionej centrum wyczerpuje się i powraca w obrazach refrenu: Krak, Krek i Krik. Owo powtórzenie, artykułowane jednak z pewnym literowym zróżnicowaniem, stanowi wyraz „formy, jego napięcia wewnętrznego, żeby uczynić pustkę, wyłonić się z pamięci, rozumu, mały, alogiczny obraz, w drżącym otwarciu"38. Wyprowadzona seria analogicznie do refrenu wzbrania się przed połączeniem przedmiotów i wyłania się, gdy prowadzi do jej nieobecności. Obraz jawi się „procesem” i pozwala uchwycić przestrzeń dowolna jako przestrzeń wyczerpania możliwości. Obraz kończy się w scenie, gdy energia się kończy. Język ten nie istnieje tylko w określonym miejscu, lecz gdy pojawia się przestrzennie wówczas, gdy zaczyna funkcjonować jako „rozległość, przestrzeń” ${ }^{39}$.

Kluczem do zrozumienia tego szkicu jest pytanie o to, „czy to nie jest również przypadek obrazu proponującego specyficzny sposób wyczerpania możliwości” ${ }^{40}$. Wyczerpanie interpretacji osadzone na marginaliach odzwierciedla, w jaki sposób „obraz jako taki tkwi w pustce poza przestrzenia, lecz również na obrzeżu słów, historii i wspomnień, magazynuje fantastyczną

\footnotetext{
${ }^{34}$ G. Deleuze, L'Épuise..., s. 72.

${ }_{35}$ Tamże, s. 74.

${ }^{36}$ Tamże.

${ }_{37}$ Tamże.

${ }^{38}$ Tamże, s. 72.

${ }^{39}$ Tamże, s. 75.

${ }^{40}$ Tamże.
} 
energię potencjalna, jaką detonuje, rozprasza" ${ }^{41}$. Deleuze porównuje sygnalizowaną potencjalność przestrzeni z „zamieszaniem, rozproszeniem tej rozważanej energii” określonej poprzez „wybuch materii języka” w rozproszonej energii, szybko się kończącej ${ }^{42}$. Relewantną cechą tej przestrzeni jest nie tyle pusta zawartość, jaka zaczyna rosnać, lecz „szalona energia gotowa do wybuchnięcia, sprawiając, iż obrazy nie trwają zbyt długo" ${ }^{43}$. Wspomniana przestrzeń istnieje tak długo, jak długo jest grana i powstaje w rozproszeniu, „wyczerpując potencjalność przestrzeni dowolnej”" ${ }^{4}$. Dla Deleuze'a instrumentem tego wyczerpania jest kamera rejestrująca Trio de fantôme. Odzwierciedla ona bowiem proces depotencjalizacji. Jednocześnie towarzyszy mu głos z offu na pierwszym planie, podczas gdy w tle:

pokój w stanie surowym ukazuje to, co szare na szarym, paletę, okno, drzwi dające nadzieję wizualności i akcji. Kiedy zostają zawieszone wszystkie możliwości, zauważamy punkt wyjścia. Kiedy kamera odkrywa postać w pierwszym planie, oświetla ona szalony uśmiech. Znika on na rzecz okna atonalnego i magnetofonu, w którym unosi się muzyka. Ktokolwiek dotyka ostatecznie swojego cyrkulujacego szału, ten tworzy obraz ${ }^{45}$.

W powyższym opisie zarysowany język obrazów, słyszenia, koloru określa przestrzeń zmierzającą na swój sposób do rozproszenia. Pomieszczenie wypełnia się „grą potencjalnościami” w przestrzeni dowolnej. Pozwala to na wykonywanie wydarzeń i odsłania, iż „przestrzeń ma potencjał w takim sensie, w jakim umożliwia realizację zdarzeń” ${ }^{46}$. W zapisie telewizyjnym tego spektaklu przestrzeń jest „całkowicie określona, poddana fragmentacji, zbliżeniu i stanowi pierwszy krok w depotencjalizacji przestrzeni, obierającej boczna

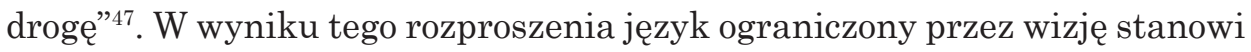
artykulację przestrzeni obrazowej postrzeganej jako „obraz mentalny”48.

Analizowane powyżej wyczerpanie interpretacji zachodzi, gdy jego wydarzenie odbywa się wtedy, gdy to, co inne, się nie zdarza. Mamy wówczas do czynienia z krystalizacja przestrzeni. Muzyk i artysta mówia, że stworzyli obrazy, wyczerpali wszelkie możliwości, choć nie zawsze są pewni, czy rzeczywiście to uczynili. Upadek zdarzenia dokonuje się w wyniku wyczerpania się potencjalności zawartej w przestrzeni Język wyczerpuje się, gdy obraz „rozprasza się tak, jak się pojawił”49. Owo rozmycie szczególnie daje

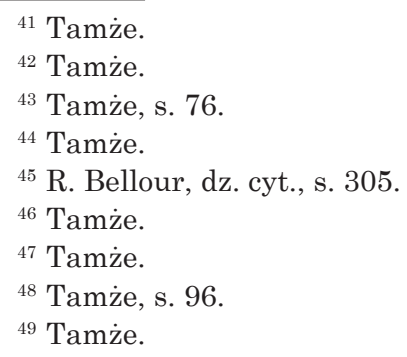


się zaobserwować w zapisie spektaklu Trio de fantôme. Obraz ten przedstawia, jak „przedmioty w przestrzeni są paradoksalnie tożsame z częścią wykadrowanej przestrzeni”"50. Ta wizja, odrywając się od przedmiotu, wyczerpuje możliwość interpretacji. Czysta forma wyczerpania dyskursu obrazuje stan potencjalności w przestrzeni dowolnej ${ }^{51}$. Wzbierana potencjalność trwa tak długo, jak trwa historia i jawi się jako możliwość interpretacji zdarzeń. Ostatnim etapem i zarazem drugim krokiem do „depotencjalizacji przestrzeni” jest „wyczerpanie” możliwych interpretacji związane z wyczerpaniem swojej potencjalności ${ }^{52}$. Znamiennym elementem owej perspektywy jest zarówno rozłączność, jak i nagłość. W dwójnasób opisane wyczerpanie obejmuje zaś to, co logiczne i psychologiczne, odpowiadając temu, co Kafka określał mianem „głowy i płuc"53. Odpowiednio zaś obu kategoriom towarzyszy paralelnie stan „snu i bezsenności” ${ }^{54}$. Najbardziej znamienną cechą owego wyczerpania „nie jest to, aby realizować to, co niemożliwe, lecz, żeby wyczerpać to, co możliwe" ${ }^{55}$. W rezultacie owego wyczerpania istnieje możliwość realizacji tych możliwości ${ }^{56}$. W obrazach telewizyjnych obserujemy, w jaki sposób potencjalność tkwiąca w języku zapisu telewizyjnego Trio de fantôme rozciagna się w „otworach, odchyleniach, ciszy”, a w konsekwencji wyczerpuje się przestrzeń widzianego spektaklu.

W świetle rozważań poczynionych w powyższym szkicu zauważmy, iż języki semiotyczne wyróżnione w telewizji, odpowiednio zaś obraz i dźwięki, okazują się znacznie ważniejsze aniżeli sam tekst sceniczny przesunięty na drugi plan. Deleuze w tym kontekście porównuje muzykę i wizję do poezji wiązanej z zerwaniem z powierzchnią słów. W dramacie tym wyjście poza ramy wcześniejszego języka przejawia się w wizjach i w głosie. Pisze on: „obraz dźwiękowo-wizualny może ponownie wyłonić się w języku poezji, "kiedy słowa przebijają się i powracają do siebie, żeby pokazać ich właściwe zewnętrze»" " ${ }^{7}$. Wzajemna wymiana i przejście tych języków od tego, co zewnętrzne, do tego, co wewnętrzne, dość jasno pokazuje, iż niniejsza „siła tekstu” Deleuze'a tkwi w „napięciu pomiędzy różnymi mediami i tym, co może pozostać utopią utopii sztuki”"58.

Zarówno pierwsze, jak i drugie ujęcie koncepcji przestrzeni dowolnej służy - jak sygnalizowałem - dwóm różnym kontekstualizacjom myślenia

\footnotetext{
${ }^{50}$ Tamże.

${ }^{51}$ Tamże, s. 86.

${ }^{52}$ Tamże.

${ }^{53}$ Tamże, s. 100.

${ }^{54}$ Tamże, s. 100.

${ }^{55}$ Tamże, s. 101.

${ }^{56}$ Tamże, s. 102.

${ }^{57}$ R. Bellour, dz. cyt., s. 306.

58 Tamże, s. 304
} 
o dualizmie obrazu, tak potencjalności przestrzeni w kinie modernistycznym, jak w telewizyjnej sztuce teatralnej. Tak pojmowane ujęcie przestrzeni nieklasycznej znaczonej poprzez fragmentację, rozmycie, rozproszenie, depotencjalizację, dookreśla opustoszałe przestrzenie tego, co audiowizualne, zbudowane z potencjalnych obrazów przygotowanych do aktualizacji $\mathrm{w}$ zdarzeniu.

\section{BIBLIOGRAFIA}

Bellour R., La chambre, [w:] R. Bellour, L'entre images 2, Paris 1999.

Bensmaïa R., L'respace quelconque» comme "personage conceptuel», "Iris" 1997, nr. 23. Chyła W., Gilles Deleuze o filmowym „obrazie-ruchu” i „obrazie-czasie”. Wprowadzenie do lektury ksiażek G. Deleuze’a poświęconych kinu, „Kwartalnik Filmowy” 1993, nr 1.

Conley T., L’événement-cinéma, „Iris” 1997, nr. 23,

Deleuze G., Kino. Obraz-czas. Obraz-ruch, przeł. J. Margański, Gdańsk 2009.

Deleuze G., L'Epuisé, suite à Samuel Beckett, postface à “Quad”, de Samuel Beckett, Paris 1992.

Marks L.U., The Skin of the Film. Intercultural Cinema, Embodiment, and the Senses, Durham \& London 2000.

Sauvagnargues A., Deleuze et l'art, Paris 2015.

Zourabichvili F., Deleuze et le possible (de l'invontolarisme en politique) [w:] Gilles Deleuze, Une vie philosophique, Paris 1998. 